\title{
A dimensão ética do pensiero debole de Gianni Vattimo: da crítica da metafísica a ética pós-metafísica
}

\author{
The ethical understanding of pensiero debole of Gianni \\ Vattimo: from a critique of metaphysics to post-metaphysical \\ ethics
}

\author{
Antonio Glaudenir Brasil Maia(*)
}

Recebido: 07/2016

Aprovado: 10/2016

\begin{abstract}
Resumo: O presente artigo explicita os argumentos para compreender a conexão entre Metafísica e violência como um dos problemas centrais da filosofia contemporânea, com base, em especial, nas reflexões de Gianni Vattimo, que denuncia a Metafísica como pensamento forte/violento. Esta é a hipótese central da crítica à Metafísica que se configura como o aspecto originário do chamado pensiero debole, que tem ulteriores desdobramentos na perspectiva de uma ética pós-metafísica.
\end{abstract}

Palavras-chave: Pensiero debole; Metafísica; Ética.

\begin{abstract}
The aim of this article is to explain the arguments for understanding the connection between metaphysics and violence, one of the central problems in contemporary philosophy, based on the reflections of Gianni Vattimo, who accuses metaphysics of being strong/violent thought. The central hypothesis of the critique of metaphysics is called pensiero debole, an imaginary aspect, which is further developed in post-metaphysical ethics.
\end{abstract}

Keywords: Pensiero debole; Metaphysics; Ethics.

\section{Introdução}

A hipótese da presença de uma dimensão ética na ontologia dell'attualità de Gianni Vattimo compreendeu, no momento inicial da pesquisa, duas possibilidades: a primeira dizia respeito à ética como dimensão da ontologia de Vattimo; e, a segunda, corresponderia ao fato de se pensar uma espécie de 'propositura' de uma ética [pós-moderna] no interior de sua ontologia. Tudo indicava a crer que a segunda assertiva parecia mais 'plausível' em virtude da publicação de certos ensaios e obras que facilmente permitiriam tal inferência ${ }^{1}$. No entanto, a investigação não poderia se limitar à análise interpretativa do conjunto das obras publicadas que versassem, por assim dizer, sobre a problemática da ética em Vattimo, pois isso incorreria no perigo de comprometer a própria originalidade da questão proposta para a tese ${ }^{2}$.

Por isso, cogitou-se que a primeira assertiva - a da ética como dimensão da ontologia dell'attualità de Vattimo - seria passível de uma investigação mais original. No entanto, a presente tese também evidenciou que a presença da ética não deve ser interpretada apenas como dimensão, mas, sobretudo, como motivação da proposta de uma ontologia dell'attualità e da produção filosófica do filósofo italiano: a preocupação ética ante as condições

\footnotetext{
*Pós-doutor em Filosofia (UFC); Doutor em Filosofia (UFPB/UFPE/UFRN); Professor de Filosofia (UVA); Professor do PPG em Filosofia (UECE) e do PROF-Filosofia (UFC); Líder do Grupo de Pesquisa Filosofia da Religião (Gephir/CNPq); Pesquisador BPI/FUNCAP.
} 
de existência o motivou em sua leitura sobre os aspectos mais fundamentais da existência humana na contemporaneidade. Embora o próprio Vattimo (2007) tenha declarado que o seu percurso filosófico compreendia o trinômio religiosofilosófico-político ${ }^{3}$, a hipótese de nossa investigação defendeu ser a Ética a premissa fundamental de seu pensamento, temática recorrente em seus diversos ensaios e obras. Isso implicou no fato de não se poder considerá-la uma problemática ao lado da religião, da estética, da hermenêutica, da política, ou seja, a ética se desdobrou no discurso de Vattimo como motivação de sua leitura do fenômeno do religioso, do estético, do político, entre outros. O próprio Vattimo declarou, em entrevista concedida ao autor que:

[...] quando faço uma ontologia da atualidade, procuro compreender qual o significado do ser na nossa situação, quero saber não por motivos teóricos, mas por motivos éticos. Não estou contente com a situação na qual vivo a política, a ética, etc. E procuro compreender o ser no mundo atual como um princípio de crítica do existente. Portanto, é sempre um motivo ético, o único motivo sério para a Filosofia é, dizemos, a situação ética" (VATTIMO apud MAIA, 2010, p. 187).

A ideia da investigação não foi explorar, de maneira exaustiva, todos esses horizontes do pensamento vattimiano, mas evidenciar que a sua ontologia dell'attualità é motivada por razões éticas, que permeiam todo o seu discurso nos mais diversos âmbitos. A tese abordou alguns temas presentes no pensamento de Vattimo, averiguando a dimensão ética como momento particular de sua ontologia da atualidade, e, com base nas obras pesquisadas, apresentasse os argumentos que justificassem a ética como premissa originária de sua ontologia. Além disso, tanto a dimensão quanto a motivação éticas indicadas não foram, pelo menos de acordo com o que foi levantado na investigação, ainda problematizadas suficientemente pela literatura filosófica ${ }^{4}$ e, no cenário brasileiro, ainda permanecia uma questão não tematizada.

A partir da hipótese delineada acima, intenta-se aqui apresentar a interpretação de Vattimo sobre a conexão entre Metafísica e violência, no sentido que concebe a tese da Metafísica como pensamento violento. Além disso, ante a questão da motivação originária de seu pensiero debole, procurase discorrer sobre os desdobramentos de tal motivação para se pensar a ética pós-metafísica no horizonte da Ontologia hermenêutica-niilista.

\section{Metafísica e violência: por uma crítica do pensamento forte}

A premissa que valida o horizonte da ética no pensamento de Gianni Vattimo reside na denúncia da relação da Metafísica com a violência, questão 
de fundo que permeia o seu discurso que considera a metafísica como pensamento forte. Já por volta dos anos 80 , em especial, com a publicação da obra As Aventuras da Diferença [1980], Vattimo anuncia que

[...] a tradição metafísica é a tradição de um pensamento 'violento' que, ao privilegiar categorias unificadoras, soberanas, generalizantes, no culto da arché, manifesta uma insegurança e um pathos de base a que reage com um excesso de defesa. Todas as categorias metafísicas (o ser e os seus atributos; a causa primeira; o homem como 'responsável'; mas também a vontade de poder, se for lida metafisicamente como afirmação e tomada de poder sobre o mundo) são categorias violentas. (VATTIMO, 1980, pp. 13-14)

A Metafísica, como pensamento fundamentalista/totalizador que tem por base a concepção do ser como presença, fundamento último e da 'verdade' como única, ilumina a reflexão crítica de Vattimo. Ele se associa a Heidegger na sua concepção da Metafísica ${ }^{5}$ como 'violência', pensamento da presença peremptória do ser como fundação que evoca, por exemplo, uma atitude (religiosa) de adoração, inviabilizando ulteriores questionamentos. Vattimo observa que Heidegger rejeita a Metafísica por esta conceber o caráter essencial do ser como simples-presença, que acarreta ainda os traços da violência que se quer evitar que se repita.

As razões da rejeição heideggeriana da concepção metafísica do ser se legitimam pelo modo de pensá-lo como simples-presença e da própria violência que isso acarreta. Ora, as motivações éticas, que já estão presentes, segundo interpreta Vattimo, em Ser e Tempo [1927], partem da concepção heideggeriana da metafísica como esquecimento e identificação do ser com o dar-se do objeto na peremptoriedade da presença, o que legitima o caráter essencialmente ético da rejeição da Metafísica como pensamento forte que fundava consequências do tipo totalitária, do tipo racionalizador da sociedade, do tipo que priva a liberdade.

Não é porque o universal conduza necessariamente à violação dos direitos do indivíduo que a Metafísica deve ser superada; aliás, neste ponto os metafísicos fazem bem ao dizer que os mesmos direitos do individuo foram frequentemente reivindicados em nome de razões metafísicas - por exemplo, nas doutrinas do direito natural. É, ao contrário, como pensamento da presença peremptória do ser como fundamento último diante do qual é possível apenas calar-se, talvez, sentir admiração - que a metafísica configura-se como pensamento violento: 0 fundamento, se se dá na evidência, incontroversa e que não deixa mais espaço para perguntas posteriores, é como uma autoridade que cala e impõe sem 'dar explicações'. (VATTIMO, 1994, p. 40)

O conceito vattimiano de 'violência' tem uma singularidade. Se em muitos teóricos a violência tem o sentido de impedir a própria vocação 
essencial de qualquer coisa, que toda a tradição filosófica concebeu sempre recorrendo a uma acepção essencialista, dominada pela Metafísica da presença, nos escritos de Vattimo, em especial, na obra Nichilismo ed Emancipazione [2003, p. 148], a violência [metafísica] é concebida

[...] em termos de 'silenciar', interrupção do diálogo, da pergunta e resposta. Isto que faz eminentemente o fundamento 'último', o qual se impõe como não ulteriormente interrogável, objeto apenas de contemplação do amor dei intellectualis.

A problemática da conexão intrínseca entre Metafísica e violência é um dos temas fundamentais da Ontologia niilista (hermenêutica) de Vattimo, o qual considera também que tal conexão representa uma das questões centrais da filosofia contemporânea ${ }^{6}$ : a conexão tem seu nascedouro no modo peremptório de se conceber metafisicamente o fundamento 'último' ante o qual resta apenas a atitude de dizer 'sim', de baixar a cabeça, de silenciar.

Em suma, isto que me repugna na fundação metafísica última é a peremptoriedade, a não perguntabilidade ulterior do fundamento, que comporta toda uma série de consequências de impensabilidade da existência. Estou convencido de que não exista nenhuma definição filosófica da violência a não ser esta: a ideia de um fundamento diante ao qual se deve apenas silenciar. (VATTIMO, 2006, p. 253)

É, por isso, que a concepção (hermenêutica-vattimiana) da violência se torna plausível. Isso em virtude do fato de compreender que a peremptoriedade silenciadora do fundamento dado 'em presença' seja suficiente para definir a violência sem recorrer às noções essencialista-naturalistas concebidas pela Metafísica. Talvez seja melhor considerar que Vattimo a interpreta que expõe uma definição da mesma, que extrai da crítica do pensamento metafísico postulado por Nietzsche e Heidegger. Vattimo rejeita a violência do fundamento metafísico - o tolhimento do perguntar - a favor da abertura dialógica, sendo que a passagem para uma racionalidade 'debole' da hermenêutica rejeita a Metafísica por razões, como se disse, estritamente éticas, ou "[...] com a assunção do destino niilista da nossa época, tomamos consciência de não poder dispor de nenhum fundamento último, fechado a cada possível legitimação da prevaricação violenta sobre o outro" (VATTIMO, 2003, p. 58).

Do ponto de vista da própria falência do pensamento metafísico, a ontologia niilista possibilita assim pensar o debilitamento do ser como dissolução das razões que justificam a violência. $O$ enfraquecer da peremptoriedade do ser metafísico implica pensar a possibilidade de uma sociedade aberta, democrática, tolerante - isso representa também a tendência, acima de tudo, política do pensamento vattimiano. O que Vattimo denuncia é a própria expropriação da liberdade, da projetualidade da existência 
historicamente situada. Dessa forma, a hermenêutica niilista de Vattimo é vista como uma filosofia motivada pela intenção notadamente ética da redução da violência, por deslegitimar toda estrutura forte que sustentava, principalmente, as éticas metafísicas da tradição Ocidental.

$\mathrm{Na}$ esteira dessa intenção ética se visualiza que a hermenêutica reage ao emergir de novos fundamentalismos e integralismos (político, religioso, moral...), após a dissolução dos fundamentos transcendentes e a perda da segurança que a Metafísica oferecia e, acima de tudo, ao próprio perigo da violência reducionista (da Metafísica) ressurgir de alguma forma. A ética pósmetafísica de Vattimo, portanto, tem como premissa suprema a redução da violência, princípio que deve orientar a Política, o Direito, a Religião, as relações socioculturais, possibilitando se pensar a negação da sociedade autoritária como positiva para a afirmação de uma sociedade alternativa, plural e, acima de tudo, mais democrática.

\section{A perspectiva ética da Ontologia hermenêutica-niilista de Vattimo}

Não há dúvida que a Ontologia hermenêutica-niilista de Gianni Vattimo tem uma motivação essencialmente ética. No entanto, ainda não foi esboçado detalhadamente o caminho propriamente dito, o percurso pelo qual a sua ontologia niilista desemboca na possibilidade de uma ética pós-moderna (pósmetafísica). A dimensão ética de sua ontologia se expressa quando propõe a 'recuperação' da racionalidade em uma instância ética que rejeita a violência do pensamento metafísico - é o que se lê, por exemplo, em La verità dell'ermeneutica, ensaio contido na obra Oltre l'Interpretazione [1994]. Com base nessa intencionalidade ética, o pensamento vattimiano se configura como a passagem da racionalidade metafísica (forte, absoluta, autoritária, violenta) para a racionalidade 'debole' (narrativo-interpretativa) em que se busca reconhecimento, nessa passagem (Vervindung) da Metafísica à Hermenêutica, dos horizontes da racionalidade na época do niilismo consumado.

Ante a aceitação inicial do caráter ético da ontologia hermenêuticaniilista vattimiana, como, então, pensar que as implicações niilistas da Hermenêutica e da Ética evitam uma 'recaída' no horizonte da Metafísica? Acrescenta-se aqui a pergunta: em que sentido as implicações niilistas da ontologia em Vattimo possibilitam uma ética pós-moderna? No discurso filosófico de Vattimo se percebe o esforço de explicitação da motivação ética da Hermenêutica, expresso em obras significativas. A Hermenêutica, apesar de ser guiada desde o princípio por uma intenção ética, não visa a atender às exigências da ética tradicional-metafísica, que postulava os imperativos, 
normas, etc. Desse modo, a Hermenêutica se apresenta, no panorama da filosofia contemporânea, como uma filosofia que, na sua crítica à Metafísica tradicional, é prioritariamente orientada em sentido ético ${ }^{7}$.

A perspectiva de uma ética com base na Hermenêutica de vocação niilista se distancia da violência intrínseca da fundamentação metafísica. A Ética no plano da hermenêutica tem o papel de limitar todas as maneiras de violência e do uso da força, como nos diz Vattimo em Más allá del sujeto [1992]. A orientação de uma ética não-metafísica tem seu prenúncio, entretanto, na obra Pensiero Debole [1983], quando Vattimo afirma o vínculo do pensiero debole com a Hermenêutica que, contaminada pelo pertencimento histórico-cultural, rejeita a posição metafísica. Dessa conexão se antever ainda, no âmbito da interpretação desse pertencimento, não uma ética de imperativos como fundada de maneira 'irrevogável', mas, uma ética dos bens, dos traços e dos estilos de vida que no plano, diga-se de passagem, de uma hermenêuticaniilista é destituída do caráter fundamental da Metafísica. Ademais, seguindo a reflexão de Vattimo, a Hermenêutica [de vocação niilista] se converte em ação ética quando abdica da pretensão metafísica de 'dogmatizar' seus pressupostos [universal e peremptório], encaminhando-se na direção da existência 'dessacralizada' em uma atitude responsável de interpretação e não fundada em imperativos unívocos.

A concepção do ser como evento e da rejeição da Metafísica, presentes no discurso de Heidegger, devem ser tomadas como válidas para a elaboração vattimiana da ontologia do debilitamento, que se constrói tendo como base a concepção não-metafísica do ser. Por esse ângulo, da ontologia debole de Vattimo deriva uma postura ética contra a violência metafísica, traço original e inelutável da propositura da ética como motivação do seu pensamento.

Se agora digo que, ao pensar a história do ser enquanto guiada pelo fio condutor da redução das estruturas fortes, sou orientado para uma ética da não-violência, não estou a tentar legitimar 'objetivamente' algumas máximas de ação com base no fato de que o ser é estruturado de uma certa maneira; limito-me a reformular de outra forma um apelo, uma chamada que me fala da tradição dentro da qual me situo e da qual, precisamente, a ontologia débil é (apenas) uma interpretação arriscada (VATTIMO, 1998, p. 36).

Admitindo a vocação niilista, evita-se que a Hermenêutica seja confundida com uma teoria metafísica dos imperativos. Em outras palavras, a vocação niilista é decisiva, no terreno da ética, para tolher da Hermenêutica a característica de indeterminação, com a qual sempre frequentemente é-lhe associada. Nessa vocação se pressupõe a radicalização como o requisito para 
evitar que a Hermenêutica permaneça no estado de indeterminação e assim seja concebida equivocadamente como a koiné da cultura contemporânea.

A hipótese da Hermenêutica como koiné da cultura contemporânea, do seu uso proliferado e 'indiscriminadamente' em diferentes correntes, autores, segundo Vattimo, contribui para a dissolução do seu significado filosófico originário. A hermenêutica, para ele, é a teoria da interpretação ligada à experiência humana, o que resultou em sua transformação em idioma comum da cultura atual. Desta sentença, se percebe o objetivo central de Vattimo: o de se repensar o sentido 'originário' da hermenêutica, com base na defesa de sua vocação niilista, traço fundamental da filosofia pós-moderna, que ele denomina de ontologia da atualidade. O que reduz a hermenêutica a genérica filosofia da cultura é a (geralmente implícita, não reconhecida) pretensão de toda metafísica de apresentar-se como uma descrição finalmente verdadeira da (permanente) 'estrutura interpretativa' da existência humana. É necessário levar a sério a contraditoriedade desta pretensão, desenvolvendo, no caso dele, uma reflexão rigorosa sobre a historicidade da hermenêutica também no sentido objetivo do genitivo. A hermenêutica não é apenas uma teoria da historicidade (dos horizontes) da verdade: é ela mesma uma verdade radicalmente histórica. Não pode pensar-se metafisicamente como descrição de uma estrutura objetiva qualquer do existir, mas só como exposição a um envio, aquele que Heidegger chama de Ge-Schick.

O que se torna evidente em toda a exposição é que o pensiero debole e a ética não-metafísica correspondem à época do pluralismo pós-moderno, constituem a recusa da categorização absoluta do pensamento metafísico, assumindo os traços da finitude, da não-fundatividade, do diálogo como características da ética em Vattimo. A rejeição da fundamentação última dos imperativos surge, na ontologia hermenêutica-niilista de Vattimo (2003), como a afirmação da situação histórica, dos valores compartilhados e da escolha de máximas de ação apresentáveis racionalmente aos interlocutores, evitando assim reconhecê-las como demonstrações apodíticas. Os valores, os discursos e as escolhas são, no horizonte da vocação hermenêutica da ética de Vattimo, radicalmente históricas, nunca cânones estáveis de um ideal normativo metafisicamente fundado. A ética inspirada na Hermenêutica se revela não como patrimônio de valores definidos uma vez por todas, mas, sobretudo, "[...] corresponde à consciência que os valores, com base aos quais, de vez em quando, se faz valer no diálogo social a preferenciabilidade de uma certa escolha, são radicalmente históricos" (VATTIMO, 1989, p. 137).

Desse modo, Vattimo defende que as possibilidades de se falar da Ética atualmente não residem nas condições transcendentais; contudo, radicam, exclusivamente, na situação concreta de (nossa) existência. A 
Filosofia (hermenêutica) abandona as essências imutáveis da Metafísica e se empenha a interpretar a historicidade, que impacta na maneira como ele discursa sobre as relações entre ética e transcendência, preterindo esta última de sua reflexão sobre a primeira, que designa de Ética sem transcendência, em Nichilismo ed emancipazione [2003]. Ao contrário de pretender alcançar o fundamento último da existência e do agir moral, a Ética deve reconhecer sua proveniência da crise da Metafísica, do fim dos imperativos morais, derivados de essências absolutas e se apresentar como interpretação da época do pluralismo cultural pós-moderno, da época do niilismo. Vattimo (2003), então, pergunta: "Se pode desenvolver um discurso ético - 'princípios' pelos quais se conseguem máximas de ação, recomendações de comportamentos, ou colocação epocal, caracterizada como dissolução dos fundamentos?"

A resposta é oferecida pelo filósofo italiano, que diz ser a dissolução o 'fundamento' com base no qual é possível argumentar sobre Ética. Ademais, Vattimo considera que a dissolução da Metafísica, por exemplo, não impede em definitivo que seja criada uma nova história, que se percebe no niilismo ativo que se radica no anúncio nietzscheano da 'morte de Deus'. Em outras palavras, a dissolução da Metafísica não abandona o pensamento à própria sorte, não o deixa órfão, pois a alusão a Nietzsche significa que da 'morte de Deus' não resulta tão somente o niilismo como dissolução de todos os valoresprincípios, mas o niilismo no qual radicam as chances de uma nova história. $O$ que se extrai, então, da Ética do reconhecimento (interpretativo) o pertencer à tradição caracterizada pela dissolução dos princípios, da fundamentação última metafísica?

\section{Por uma ética pós-metafísica}

Se a Ética não se orienta mais por princípios primeiros, a ideia de transcendência que sempre marcou a tradição ético-filosófica se dissolve, o que implica uma nova postura Ética na pós-modernidade. Vattimo esclarece que a negação da transcendência diz respeito à negação da Ética pensada com respeito a leis derivadas de essências (estruturas) metafísicas, que considera ser carente de 'eticidade'. Para ele, a perda da dimensão de transcendência na ética não deve ser encarada como catastrófica, mas vista como a vocação da própria ética pós-metafísica, como expressão do sentido emancipativo que está presente na dissolução dos absolutos metafísicos. Em outras palavras, uma ética pós-metafísica, na verdade, não procura extrair suas 'leis' de essências metafísicas, de uma dimensão transcendente que se impõe categoricamente à consciência individual. A dimensão social deve impactar no 
discurso sobre a ética para ser legitimamente reconhecido como eticamente positivo, que possibilita também desenvolver um discurso ético-crítico do existente e das escolhas ulteriores, não recorrendo à transcendência que marcou os discursos metafísicos sobre ética.

\begin{abstract}
As razões para preferir a leitura 'pós-metafísica' do discurso atual da ética são mais ou menos as mesmas que avançam para recomendar uma leitura pós-metafísica da modernidade e de seus êxitos atuais. São razões 'históricas', em muitos sentidos da palavra: valem como argumentos 'ad hominem', por isso, situados dentro da mesma situação que se propõem interpretar (como é, de resto, da natureza da interpretação); é, também históricas, noutro sentido: olham a história que vivemos e estamos vivendo. Evocam, como seu desfundamento prático-teórico, o fim do colonialismo, a descoberta da existência de outras culturas, que não se deixam enquadrar em uma linha evolutiva que se concluiria com a civilização ocidental e sobre a qual elas teriam uma posição mais atrasada e primitiva (VATTIMO, 2003, p. 74).
\end{abstract}

É importante advertir que uma leitura pós-metafísica da Ética não possui razões essenciais, absolutas. A historicidade das razões da leitura pósmetafísica se constitui como rejeição/dissolução dos absolutos metafísicos que serviram de fundamentação da Ética. Vattimo comenta que a crise da Ética é o resultado do descrédito a que chegou toda orientação de fundamentação da metafísica. Vattimo também registra que a crise da Metafísica representa a crise dos valores últimos, defende, reportando-se para tanto à escola da suspeita (Marx, Nietzsche, Freud), que a pretensão da fundação do ético com base em um valor último-absoluto se dissolveu, o que implica a crise ética que, "[...] sob os golpes destes vários tipos de críticas, parece que a ideia de um valor, que possa valer como fundamento da ética e da política, a ideia de um valor-base, dissolveu-se" (VATTIMO, 1990a, p. 81). Por isso, defende que a Ética deve reconhecer a sua condição de não-fundatividade metafísica, considerar-se herdeira de sua crise, da dissolução dos fundamentos, dos primeiros princípios, para reportar-se ao pluralismo cultural irredutível, que configura o ethos pós-moderno. Relativismo de uma época do encontro mais frequente de culturas, histórias e tradições diversas, reflete a eticidade que garante o diálogo e a tolerância em vez da preocupação em fundar morais provisórias.

A crítica à ética metafísica, dos princípios imutáveis, dos imperativos categóricos absolutos auxilia a compreensão da intenção de Vattimo de propor um modo alternativo de se pensar os direitos/deveres, sem reduzir a Ética à doutrina de deveres, ao campo restrito da Filosofia ${ }^{8}$. Não obstante a reflexão de Vattimo não restringir a ética a um setor especialístico da Filosofia e/ou à história das teorias normativas, a concebe como uma espécie de 'doutrina' da 
vivibilidade. Tal concepção, portanto, caminha na direção do mundo da pluralidade de estilos de vida, da 'descrição' e da análise de culturas, o que se registra na história da Ética nos dois séculos passados. Nesse sentido, Vattimo escreve:

[...] as histórias da ética, mais advertidas [...] põem sempre os acontecimentos da ética sobre o horizonte da sociedade, da cultura, das visões de mundo pertencentes às diversas épocas. Em geral, pode-se observar que, enquanto não é possível educar a moralidade propondo textos de ética filosófica, ou exatamente, manuais, a formação do próprio ethos pessoal passa frequentemente por meio da leitura de romances e poesias. Nesse sentido, pode-se dizer que a ética vivida é também, em qualquer modo, questão de gosto (VATTIMO, 2002, p. 77).

Na obra Tecnica ed esistenza [2002], a leitura de Vattimo sobre a Ética não a limita às correntes filosóficas e aos filósofos. Do ponto de vista de sua ontologia da atualidade, a Ética abrange os artistas, os poetas, os críticos literários, os antropólogos, etc., que, no aspecto mais abrangente da Ética, pode ser observado em uma literatura mais heterogênea, menos especializada, distinta dos grandes tratados sobre Ética. Ética e sociedade vistas, então, em uma simbiose que permite compreendê-las para além das enciclopédias e das categorias especializadas, como consta na própria história da tradição ética ${ }^{9}$. A passagem permite também considerar que o significado ético que Vattimo imprime não se identifica necessariamente com os temas (bem, dever, norma, etc.) defendidos pela moral tradicional. O que implica reconhecer, sem dúvida, a existência de uma possível ética na literatura, na arte, na antropologia cultural, portanto, uma ética não restrita aos padrões convencionais que se delinearam ao longo da história da assim chamada ética filosófica.

Contra tal concepção eu proponho uma ética - se pode ainda definir assim baseada sobre argumentação puramente retórica, isto é, um sistema de argumentos ad hominem [...]. Fala-se a um pai de família, busca-se convencê-lo a dirigir com prudência, recordando-lhe os filhos, um pouco de como estava escrito sobre certos porta-retratos de qualquer ano passado: 'Papai vá devagar', 'Não corra papai'. Falase a uma comunidade que acredita em certos comportamentos, nos referindo àqueles mesmos valores, que não são necessariamente eternos, mas podem funcionar persuasivamente para orientar a comunidade em um sentido ou noutro, ou também simplesmente para encontrar um terreno comum do discurso. Esta eu essencialmente imagino coma a alternativa possível, do tipo retórico, o sublinho, a uma fundação metafísica, com o risco de fanatismo em ética e em política (VATTIMO, 1990b, p. 86).

Com a perspectiva da contextualização histórico-social da Ética, já anunciada em meados dos séculos XIX e XX, se 'abandona', segundo Vattimo, o fundamento transcendente. A Ética se caracteriza, por isso, como uma 
versão secularizada do 'progresso' do mundo histórico, que abrange desde a contextualização dos eventos espirituais até a afirmação do relativismo histórico, no sentido de que os valores (verdadeiro, bem...) sejam abalizados em tempo e lugar respectivos, nunca derivados de essências metafísicas. Ética como ethos, costumes, cultura compartilhada em determinado contexto de uma época ou sociedade, ou seja, uma ética epocal-histórica que Vattimo interpreta com base em sua ontologia niilista. Uma ética da interpretação, então, em que ética e interpretação coincidem e são vistas em uma situação histórico-destinal, onde a ética é concebida como interpretação e esta se apresenta como ética.

A ética pós-metafísica deve reconhecer seu pertencer à tradição caracterizada pela dissolução dos princípios metafísicos, assumindo tal dissolução como ponto de pertencimento e caminho para uma ética nãometafísica, que não se constitui como aplicação prática de uma certeza teórica acerca de fundamentos últimos. O raciocínio vattimiano manifesta a implicação que existe entre uma ética da proveniência da época da dissolução dos fundamentos em direção do reconhecimento da própria finitude como traço inconfundível de uma ética pós-moderna, portanto, pós-metafísica que se realiza como uma ética da finitude.

\footnotetext{
Uma ética da finitude é aquela que busca permanecer fiel à descoberta da colocação sempre insuperavelmente finita da própria proveniência sem esquecer as implicações pluralísticas desta descoberta. Estou com os santos e com os fatos na taberna, e não posso nunca iludir-me de colocar-me numa condição superior; também quando pronuncio esta frase em um discurso filosófico, estou apenas em uma outra condição que impõe determinados empenhos, como qualquer que seja outra: a particular condição de filósofo, de ensaísta, de crítico, nunca de homem universal (VATTIMO, 2003, p. 55).
}

Em Etica dell'interpretazione [1989], Vattimo assinala, por isso, que a dissolução da Metafísica é o pressuposto fundamental para se pensar uma ética pós-moderna, assumindo a tarefa de refletir sobre a historicidade da existência humana. O pluralismo pós-moderno exige uma resposta do pensamento filosófico que leve em consideração as circunstâncias históricas, não fundadas metafisicamente. Nesse horizonte de pertencimento à época da falência da Metafísica se revela a exigência de uma nova postura (da) ética que diverge das éticas centradas nos princípios metafísicos, nos valores últimos ${ }^{10}$. Uma ética pós-metafísica é uma ética da proveniência da época do niilismo, que corresponde à condição do fim da Metafísica em Heidegger e da 'morte de Deus' em Nietzsche. Vattimo sustenta que:

[...] a escolha entre isto que vale e isto que não vale da herança cultural da qual provínhamos será feita em base ao critério da redução da violência e em nome de 
uma racionalidade entendida como discurso-diálogo entre posições finitas que se reconhecem como tais, e que, por isto, não têm a tentação do impor-se legitimamente (enquanto convalidadas por um principio primeiro) sobre aquelas dos outros (VATTIMO, 2003, p. 57).

A dimensão da proveniência que se verifica no discurso de Vattimo [1996] legitima as escolhas no campo da ética. Por isso, muito acertadamente se prenuncia uma ética contra a violência como proveniente da ontologia niilista, que não representa uma 'recaída' na Metafísica, pois o ser vem pensado para além dos limites da ontologia tradicional metafísica: o ser vem interpretado como herança, apelo, proveniência... Ora, é justamente aqui que se conclui a tese do debilitamento do ser que representa a dissolução da perspectiva da moralidade como correspondência à essências metafísicas, explicitando o dado da coerência do discurso de Vattimo - a rejeição da violência da fundamentação metafísica a favor da abertura dialógica da ética na pós-modernidade.

A escuta da herança da dissolução dos princípios metafísicos não se limita apenas à 'desvalorização de todos os valores', mas a retomadaprossecução de determinados padrões que se herda. A validade de uma norma, no entanto, depende de uma espécie de fio condutor que ilumina a interpretação dessa herança. No caso de uma ética pós-metafísica, da finitude, da proveniência - nomes que podem ser atribuídos à Ética, digamos, de Vattimo - o niilismo é o guia na época da dissolução dos fundamentos últimos, do abandono da violência, da negação do autoritarismo dos primeiros princípios que impedem, por um lado, ulteriores interrogações, o diálogo com a época da proveniência. Vattimo [2003], por outro lado, nos fala que o discurso da ética da finitude é apenas exortativo, provocativo, pois o niilismo como fio condutor da redução da violência talvez seja admitido apenas interpretativamente, nunca demonstrado.

É, nesse sentido, que na orientação vattimiana se admite a vocação niilista como possibilidade de se pensar uma ética não-metafísica haja vista não se apresentar como teoria metafísica de imperativos. Essa vocação permeia à ideia de ontologia hermenêutica (ontologia niilista) que busca dissolver a violência e o esquecimento do ser como elementos constituintes da Metafísica ${ }^{11}$. Destarte, Vattimo [1989] atribui grande importância à concepção hermenêutica da ética que, para "evitar" as implicações metafísicas, se apresenta como interpretação em si mesma, respondendo ao aparecer histórico-destinal do ser e, naquela atitude de rememoração heideggeriana que concebe o ser como eventualidade (esta também nos termos nietzscheano), não pode ser considerada uma retomada da pretensão metafísica do principio fundamental-último. 
Vattimo também afirma que o reconhecimento da vocação hermenêutica-niilista da ética representa o abandono da pretensão de se reduzir o sentido da experiência da verdade ao dado objetivo (como defendeu o cientificismo). Adverte ainda que a hipótese de tal vocação não deva ser confundida com uma retomada das éticas fundadas nos imperativos e normas absolutas, como sempre pretendeu a Metafísica.

\footnotetext{
Se uma ética 'hermenêutica' é possível [...] ela tem a necessidade de uma ontologia niilista, no sentido que se disse; a qual pode argumentar-se somente como interpretação dos eventos, leitura dos 'sinais dos tempos', escuta das mensagens; [...] como uma 'ontologia da atualidade', para a qual é decisivo o referimento a certa imagem da modernidade, do seu destino de secularização, do seu eventual 'fim'. Mais que 'fundar-se' sobre esta atividade interpretativa do acontecer do ser, a ética hermenêutica se exercita antes de tudo em tal atividade; é também, antes de qualquer coisa, embora (talvez) não exclusivamente, neste sentido, uma ética da interpretação (VATTIMO, 1989, p. 09).
}

A retomada da obra Etica dell'Interpretazione [1989], principalmente, do início em que Vattimo anuncia sua intenção com a proposta de uma ética hermenêutica, é motivada pelo interesse de reafirmar certas teses presentes no discurso de Vattimo. Longe de representar uma repetição argumentativa, significa o aspecto mais apropriado de uma leitura sobre a ontologia hermenêutica-niilista vattimiana. Desse modo, a concepção da ética da interpretação, proposta por Vattimo, não tem a pretensão de alcançar um ideal normativo-metafísico. Tal ética busca, pelo contrário, assumir o seu próprio destino niilista e - inspirando-se em uma ontologia da redução da violência - se reconhece como pensamento da época do fim da Metafísica (época do niilismo), como abertura que possibilita se pensar uma ética pós-moderna no horizonte da ontologia da atualidade de Vattimo. Embora não se possa indicar que orientações éticas, digamos assim, estão presentes no discurso de Vattimo, pois não sistematizou um tratado sobre ética, sendo possível defender que o ponto de convergência das obras e ensaios se assenta na defesa do 'imperativo' da redução da violência, daquilo que impede o diálogo, da rejeição das pretensões universalizantes/totalizantes seja da Filosofia, da religião, da política, permitindo uma relação de reconhecimento da situacionalidade histórica das outras culturas, pessoas, dialetos...

\section{Referências}

D'ARCAIS, Paolo Flores. Per uma critica esistenzial-empirista dell'ermeneutica. Almanacco di filosofia. v. 5. Roma: Micromega, 2011. 
GADAMER, Hans-Georg. A Razão na época da ciência. Rio de Janeiro: Tempo Brasileiro, 1983

GÁLVEZ, J. A.B. La 'ética de la interpretación', de Gianni Vattimo, en el contexto de la posmodernidad. A Parte Rei. Revista de Filosofia. Madrid, noviembre 2007

GIORGIO, Giovanni. Nichilismo ermeneutico e política. A Parte Rei. Revista de Filosofia. Madrid, noviembre, 2007.

HEIDEGGER, M. Ser e Tempo [1927]. Rio de Janeiro: Vozes, 1997. . A superação da Metafísica. IN: Ensaios e Conferências [1954]. Rio de Janeiro: Vozes, 1997.

MAIA, A. G. B. A dimensão ética da Ontologia dell'Attualità de Gianni Vattimo. Tese de Doutorado. Universidade Federal de Pernambuco, 2010. 201 páginas. MATTIA, Daniele. Gianni Vattimo - l'etica dell'interpretazione. Perugia: Firenze atheneum, 2002.

VATTIMO, G. et al. Le ragioni etico-politiche dell'ermeneutica. Isaiah Berlin, Amartya Kumar Sen, Vittorio Mathieu. Torino: Giovanni Agnelli, 1990b.

2003. . Nichilismo ed emancipazione. Etica, política, diritto. Milano: Garzanti,

. Ecce Comu. Como si ri-diventa ciò che si era. Roma: Fazi, 2007.

. Etica dell'Interpretazione. Torino: Rosenberg \& Sellier, 1989.

Filosofia al presente. Conversazioni con F. Barone, R. Bodei, I.

Mancini, V. Mathieu, M. Perniola, P.A. Rovatti, E. Severino, C. Sini. Milano: Garzanti, 1990a.

. Entrevista. IN: CULT, n. 126, julho/2008.

. Revista CULT 44, março/2001.

. Tecnica ed Esistenza.Una mappa filosofica del Novecento. Milano:

Paravia, 2002.

- As Aventuras da Diferença: o que significa pensar depois de Heidegger e Nietzsche [1980]. Lisboa: Edições 70, 1988.

1996.

- Diferir a Metafísica. IN: O que nos faz pensar. n. 10, V. 1, outubro de

- Más allá del sujeto. Nietzsche, Heidegger y la hermenêutica. Barcelona: Paidós, 1992.

. Oltre l'Interpretazione. II significato dell'ermeneutica per la filosofia (Lezioni italiane). Roma-Bari: Laterza, 1994.

- La Vita dell'Altro. Bioetica senza Metafisica. Bioetica senza Metafisica.

Lungro di Cosenza: Marco Editore, 2006b.

. ROVATTI, A.P. II Pensiero Debole. Milano: Feltrinelli Editore, 1983.

Metaphysics and Violence. IN: ZABALA, S. (org.) Weakening Philosophy: essays in honour of Gianni Vattimo. Mc Gill-Queen's University 
Press, Montreal Kingston, London, Ithaca, 2007b.

${ }^{1}$ A título de alusão, cito as obras: Etica dell'Interpretazione [1989], Oltre l'Interpretazione [1994], Tecnica ed Esistenza [2002], Nichilismo ed Emancipazione [2003], La Vita dell'altro Bioetica senza metafisica [2006b].

${ }^{2}$ A questão foi tratada por ocasião da realização do nosso curso de doutorado em Filosofia (UFPB/UFPE/UFRN). É claro que neste artigo não serão tratados todos os argumentos e questões sobre o assunto. A quem interessar, sugere-se consultar: MAIA, A. G. B. A dimensão ética da Ontologia dell'Attualità de Gianni Vattimo. Tese de doutorado. Universidade Federal de Pernambuco, 2010.

${ }^{3} \mathrm{O}$ itinerário vattimiano percorre esse trinômio interdependente, que não se pode pensar o filosófico que não seja 'religioso' e 'político', vice-versa. (Cf. VATTIMO, Gianni. Ecce Comu. Como si ri-diventa ciò che si era. Roma: Fazi, 2007a, p. 93.).

${ }^{4}$ Cito, entre outras, os trabalhos: GÁLVEZ, J. A.B. La 'ética de la interpretación', de Gianni Vattimo, en el contexto de la posmodernidad. A Parte Rei. Revista de Filosofia. Madrid, noviembre 2007; MATTIA, Daniele. Gianni Vattimo - l'etica dell'interpretazione. Perugia: Firenze atheneum, 2002; GIORGIO, Giovanni. Nichilismo ermeneutico e política. A Parte Rei. Revista de Filosofia. Madrid, noviembre, 2007. De fato, os vários intérpretes focalizaram prevalentemente o aspecto filosófico do percurso especulativo de Vattimo ou, quando muito, a sua reflexão sobre o religioso-teológico.

${ }^{5}$ De acordo com Vattimo: "Na perspectiva heideggeriana, como se sabe, Metafísica é aquele pensamento que considera o ser como um sistema de objetos rigorosamente concatenados entre si por um princípio de causalidade. Esta concatenação de todos os entes segundo o nexo de fundação que na Metafísica antiga - por exemplo e, sobretudo, Aristóteles - é somente cultivada, a nível ideal da mente, na modernidade que se atua realmente a obra da técnica; a qual, portanto, é a Metafísica realizada". (VATTIMO, Gianni. Etica dell'Interpretazione, 1989, p. 66.).

${ }^{6}$ Cf. VATTIMO, G. Metaphysics and Violence. IN: ZABALA, S. (org.) Weakening Philosophy: essays in honour of Gianni Vattimo. Mc Gill-Queen's University Press, Montreal Kingston, London, Ithaca, 2007b.

${ }^{7}$ Vattimo cita, por exemplo, Gadamer de Verdade e Método em que acentua que a filosofia prática se aproxima do significado da Hermenêutica, ainda por compreender que a obra gadameriana tem a Ética como um de seus temas essenciais. (Cf. VATTIMO, Gianni. Ética dell'Interpretazione. 1989, p. 135.). Em A Razão na época da ciência, em particular, no ensaio Hermenêutica como filosofia prática, Gadamer considera a hermenêutica filosófica não apenas um novo procedimento de interpretação, isto é, "não se trata, pois, em nenhum caso, de uma teoria da arte que queira indicar como deveria ser a compreensão [...]. A compreensão é algo mais que aplicação artificial de uma capacidade. É sempre também o atingimento de uma autocompreensão mais ampla e profunda. Mas isto significa que a hermenêutica é filosofia e, enquanto filosofia, filosofia prática". (GADAMER, Hans-Georg. A Razão na época da ciência. Rio de Janeiro: Tempo Brasileiro, 1983, p. 76.).

${ }^{8}$ Por isso, Vattimo destaca que "Nietzsche dizia que a desvalorização diz respeito aos valores supremos, mas não a todos os valores, porque ele queria que se criassem sempre novos valores ou nascessem sempre novos deuses. Esse é o ponto: nós devemos constituir uma ética do projeto, e não uma ética do reflexo da natureza, da ordem, do necessário, etc.". (VATTIMO, Gianni. Revista CULT 44, março de 2001, p. 09.). 


\footnotetext{
${ }^{9}$ Vattimo anuncia que: "De fato, a história da ética, sobretudo, nos últimos dois séculos, não é apenas aquela das teorias normativas, mas considera também a descrição e a análise de culturas. Antes de tudo, com o enfraquecer-se da crença em verdades universais [...] ética e antropologia parecem sempre mais próximas (VATTIMO, Gianni. Tecnica ed esistenza. 2002, p. 77.).

${ }_{10}$ Mattia, seguindo a reflexão de Vattimo, defende que: "Com a redução do valor supremo e com a consequente proliferação e mobilidade dos valores, segundo Vattimo, se esquece o imperativo da verdade porque as condições de existência adquirem possibilidades de menor violência; é, portanto, a consumação e sucessiva superficialidade dos valores últimos a raiz do niilismo 'consumado' e a abertura de uma nova eticidade". (MATTIA, Danielle. Gianni Vattimo. L'etica dell'interpretazione. 2002, p. 18.).

${ }^{11}$ A luta contra a Metafísica é, segundo Vattimo, a luta contra o autoritarismo, que tem no pensiero debole a fonte da inspiração de oposição a ela. "O pensamento fraco é também, um pensamento que respeita a esperança da maioria, no fundo, um pensamento autenticamente democrático. Eu estou com os fracos porque, em muitos sentidos, sou um deles, e não porque haja para mim uma razão metafísica para preferi-los". (VATTIMO, Gianni. Entrevista. IN: CULT, n. 126 , julho/2008, p. 15.).
} 